\title{
Perencanaan Komunikasi Pemasaran di Masa Pandemi (Studi Kasus Interaksi Simbolik Hann Prawira Fotografi)
}

\author{
Karl Vincent, Muhammad Adi Pribadi \\ karlvinceent@gmail.com,adip@fikom.untar.ac.id \\ Fakultas Ilmu Komunikasi Universitas Tarumanagara
}

\begin{abstract}
In marketing activities, marketing communication planning plays a role and is applied as a sales and promotion solution for a product to the public which uses several effective and interactive ways and the content of its service products can be felt by all target audiences. Hann Prawira Photography is a service provider company in the form of photography, the service company does photo shoots for Indonesian or foreign artists, not only shooting artists but also working on photo shoots for commercial needs, such as shooting for billboards, websites and others. This communication research focuses on symbolic interactions and has a very important role, in which Hann Prawira Photography uses this symbolic interaction by presenting his work through photography and also the importance of relationships with consumers. This study uses a qualitative methodology with a strategy and case studies. The data were collected using in-depth interviews directly to the founder of Hann Prawira Photography and his team. The conclusion of this research is that it has 8 marketing communication plans, namely, business objectives, target market, competitors, communication themes, tactical, implementation, monitoring, communication channels and evaluation. At all these stages there are symbolic interactions such as organizational goals, to the company's vision and mission.
\end{abstract}

Keywords: case studies, hann prawira photography, marketing communications, symbolic interactionism

\begin{abstract}
Abstrak
Di dalam kegiatan pemasaran, perencanaan komunikasi pemasaran berperan dan diterapkan sebagai solusi penjualan dan promosi untuk suatu produk kepada masyarakat yang dimana menggunakan beberapa cara yang efektif dan interaktif juga isi produk pelayanannya dapat dirasakan oleh semua target audience. Hann Prawira Fotografi merupakan suatu perusahaan penyedia jasa dalam bentuk fotografi, perusahaan jasa tersebut mengerjakan pemotretan artis indonesia ataupun luar negeri, tidak hanya pemotretan artis tetapi juga mengerjakan pemotretan untuk kebutuhan komersial, seperti pemotretan untuk billboard, website dan lainnya. Penelitian komunikasi ini berfokus pada interaksi simbolik dan mempunyai peran yang sangat penting, yang di mana Hann Prawira Fotografi sangat menggunakan interaksi simbolik ini dengan mempersembahkan karyanya lewat fotografi dan juga pentingnya hubungan dengan konsumen. Penelitian ini menggunakan metodologi kualitatif dengan strategi dan studi kasus. Data-data dikumpulkan menggunakan wawancara mendalam langsung kepada pendiri Hann Prawira Fotografi dan tim. Kesimpulan dari penelitian ini yakni memiliki 8 perencanaan komunikasi pemasaran yaitu, Tujuan bisnis, Target Market, Kompetitor, Tema Komunikasi, Taktis, Implementasi, Monitoring, saluran komunikasi dan Evaluasi. Pada semua tahapan tersebut terdapat interaksi simbolik seperti, tujuan organisasi, sampai visi dan misi perusahaan.
\end{abstract}

Kata Kunci: hann prawira fotografi, interaksi simbolik, komunikasi pemasaran, studi kasus 
Karl Vincent, Muhammad Adi Pribadi: Perencanaan Komunikasi Pemasaran di Masa Pandemi (Studi Kasus Interaksi Simbolik Hann Prawira Fotografi)

\section{Pendahuluan}

Komunikasi di era sekarang ini sudah mengalami banyak perkembangan dan perubahan yang sangat pesat. Perkembangan dan perubahan tersebut terjadi karena berkembangnya teknologi komunikasi dari masa ke masa, seperti alat penghubung komunikasi antara satu dengan yang lainnya.

Komunikasi terjadi tanpa di sadari, dalam kehidupan masyarakat tak satupun manusia yang tidak berkomunikasi. Manusia tidak hanya berkomunikasi saja namun di dalam komunikasi itu ada interaksi simbolik. Interaksi yang di gunakan dalam kehidupan bersosial pada dasarnya menggunakan simbol-simbol.

Hann Prawira Fotografi merupakan suatu perusahaan penyedia jasa dalam bentuk fotografi, perusahaan jasa tersebut mengerjakan pemotretan artis Indonesia ataupun luar negeri, tidak hanya pemotretan artis tetapi juga mengerjakan pemotretan untuk kebutuhan komersial, seperti pemotretan untuk billboard, website dan lainnya. Hann Prawira Fotografi Menggunakan metode Integrated Marketing Communication dalam pemasarannya.

Teori interaksi simbolik menjadi pedoman atau acuan dalam setiap kegiatan yang berlangsung, sehingga dapat di artikan bahwa teori interaksi simbolik adalah ide - ide dalam berinteraksi dengan masyarakat berbentuk simbol - simbol verbal dan nonverbal (West dan Turner, 2013). Munculnya interaksi karena adanya respon antara kedua belah pihak dan juga adanya pemahaman yang sama mengenai makna tersebut.

George Herbert Mead mendefinisikan teori interaksi simbolik merupakan teori yang membahas tentang berbagai aspek subjektif manusia di dalam kehidupan sosial. Teori interaksi simbolik mempunyai perspektif yang menggunakan dasar pemikiran yaitu proses sosial, perilaku manusia yang terkait dengan makna (West dan Turner, 2013).

George Herbert Mead mempunyai tiga konsep pemikiran dasar yang paling penting dalam teori interaksi simbolik yaitu Mind, Self, Society. tiga konsep ini merupakan konsep yang saling berkaitan satu dengan yang lain, hal ini menjadi sebuah refrensi dari teori interaksi simbolik secara luas.

\section{Metode Penelitian}

Metode yang di gunakan untuk penelitian ini adalah metode kualitatif, menurut Moeloeng dapat di definisikan bahwa metode ini mempunyai tujuan untuk lebih mengerti fenomena atau kejadian yang di alami oleh subjek, dimana di dalamnya melibatkan perilaku, persepsi, motivasi, tindakan dan setelah itu dideskripsikan dengan kata-kata dengan metode yang alamiah.

Ada tiga dalam penelitian studi kasus yaitu eksplantoris, eksploratoris, dan deskriptif. Secara umum, studi kasus sangat cocok apabila dikaitkan dengan penelitian yang pertanyaannya bersifat how atau why. Dalam praktek nya peneliti studi kasus perlu lebih memusatkan perhatiannya pada pendesainan dan penyelenggaraannya agar dapat menangani kritik - kritik tertentu terhadap tipe pilihannya (Yin, 2013).

Dalam penelitian ini menggunakan metode pengumpulan data observasi, wawancara mendalam, dokumentasi, dan rekaman arsip. Subjek yang ada di penelitian ini adalah narasumber atau informan yang kredibel terhadap masalah yang sedang di teliti oleh peneliti. Subjek bisa berupa individu atau komunitas atau organisasi. Penting untuk narasumber agar dapat memberi informasi yang valid untuk membantu dalam menemukan hasil penelitiannya. 
Penelitian ini juga menggunakan tipe studi kasus eksplanatoris dimana mempunyai kecenderungan membuat, meramu suatu penjelasan-penjelasan yang cukup kuat untuk suatu peristiwa yang sama dan juga menunjukan bahwa penjelasan itu tak menutup kemungkinan untuk digunakan pada situasi lain.

\section{Hasil Temuan dan Diskusi}

Hann Prawira Fotografi menjadi bagian dari konsep Generelized Others yang dijelaskan oleh Mead. Sebagaimana diberlakukan nya peraturan baru (PSBB) dari pemerintah yang membuat Hann Prawira Fotografi harus mengikuti aturan tersebut untuk meminimalisirkan rantai penyebaran covid-19,

Pembahasan berdasarkan wawancara mendalam yang peneliti lakukan dengan Hann Prawira Fotografi sangat erat kaitan nya dengan teamwork pada proses pembentukan perencanaan komunikasi pemasaran yang disambungkan dengan teori terkait dalam penelitian ini adalah Teori Interaksi Simbolik dan Perencanaan Komunikasi Pemasaran. Sesuai dengan visi dan misi dari Hann Prawira Fotografi bahwa visi misi tersebut sejalan dengan Particular Others.

\section{Peraturan}

Tujuan suatu aturan adalah untuk terciptanya keteraturan dalam pekerjaan masing-masing staff atau karyawan dan juga untuk memajukan perusahaan ke arah yang lebih baik. Juga dengan aturan-aturan yang ada, staff atau karyawan tidak bisa meremehkan job desk nya. Pastinya setiap perusahaan apapun itu memiliki aturan yang sudah di sepakati.Artinya dalam hal ini Hann Prawira Fotografi sejalan dengan particular others (masyarakat atau society)

\section{Perencanaan komunikasi pemasaran}

Sembilan Model pemasaran ini dapat memberikan dampak yang bagi Hann Prawira Fotografi dalam perencanaan komunikasi pemasaran. Penelitian ini juga membahas strategi komunikasi pemasaran yang dijalankan oleh Hann Prawira Fotografi yaitu, tujuan bisnis, target market, kompetitor, tema komunikasi, saluran komunikasi, taktis, implementasi, monitoring, dan evaluasi.

\section{Tujuan Bisnis}

Tujuan bisnis Hann Prawira Fotografi menggaet klien-klien komersial. Ini bisa dikaitkan dengan generalized other dimana bisnis mempunyai aturan dan peranan sehingga visi dan misi perusahaan selaras dengan nilai dan konsep perusahaan.

\section{Strategi Pemasaran}

Secara luas pemasaran adalah proses sosial yang artinya penjual mendapatkan apa yang mereka butuhkan melalui pertukaran nilai dengan orang lain. Karena itu pemasaran dapat di definisikan sebagai bentuk proses dimana perusahaan menciptakan nilai yang baik untuk pelanggan serta menciptakan adanya hubungan baik jangka panjang dengan pelanggan yang bertujuan mendapatkan nilai yang bagus dari pelanggan sebagai bentuk apresiasi untuk perusahaan tersebut.

\section{Target Market}

Target market yang dimaksud yaitu suatu kelompok konsumen yang menjadi sasaran pendekatan perusahaan untuk membeli atau menggunakan jasa produk yang 
di jual. Misalnya setiap target pemasaran biasanya mempunyai rentan umur, sifat dan karakter yang hampir sama.

\title{
Kompetitor
}

Kompetitor menjadi penting. Karena jika kita mengenali kompetitor kita, maka kita akan menjadi lebih mudah dalam memasarkan banrang atau jasa yang kita jual. Memang bukan untuk menjatuhkan kompetitor kita, setidaknya memudahkan perusahaan dalam pengambilan keputusan, strategi-straegi yang di gunakan sampai mengetahui kelemahan dan kelebihan kompetitor. Kompetitor di Hann Prawira Fotografi adalah orang-orang yang juga menjalani bisnis di jasa ini khususnya fotografi.

\section{Tema Komunikasi}

Dalam pembahasan ini Tema komunikasi menjadi penting. Karena jika ini tidak di terapkan, hasil kareya menjadi tidak unik dan menarik, di sini menjelaskan Bahwa semua seniman harus ada ciri khas masing-masing yang menunjukan bahwa itulah karyanya seorang fotografer tertentu. Hann Prawira Fotografi terkenal dengan gaya foto fashionnya, kuat, dan ekspresif.

\section{Saluran Komunikasi}

Secara luas saluran komunikasi adalah media-media untuk memasarkan atau menyuarakan produk atau jasa agar masyarakat dapat lebih mengenali perusahaan tersebut. Dengan begitu dapat membantu perusahaan dalam menaikan penjualan. Saluran komunikasi yang beliau gunakan adalah Instagarm, biasa juga ada di majalahmajalah dan website.

\section{Evaluasi}

Hal ini menjadi bagian penting dalam melakukan keputusan dan hasil kinerja yang diberikan oleh tim Hann Prawira Fotografi, Karena menentukan tujuan yang akan dicapai dan bagaimana hasil perencanaan yang dilakukan apakah sudah mencapai target yang diharapkan.perencanaan komunikasi pemasaran ini mempunyai keselarasan dengan penelitian perencanaan komunikasi pemasaran (Pribadi et al., 2018). Perencanaan komunikasi ini mempunyai kesamaan dengan teori -teori yang sudah diberlakukan sejak awal.

Gambar 1. Logo Hann Prawira Fotografi

\section{HANN PRAWIRA PHOTOGRAPHY}

\author{
Sumber: Dokumentasi Hann Prawira Fotografi
}


Gambar 2. Struktur Organisasi Kopi Lain Hati Sukasari Bogor

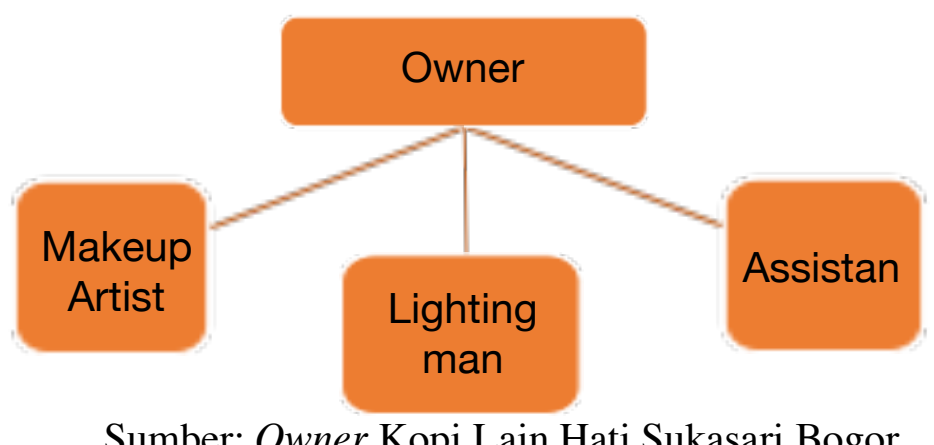

\section{Simpulan}

Berdasarkan hasil penjelasan diatas, maka kesimpulan dalam penelitian ini adalah sebagai berikut:

1. Hann Prawira Fotografi memiliki konsep yang sejalan dengan Generelized Others dalam menjalankan usaha nya.

2. Dalam Perencanaan Komunikasi Pemasaran di Hann Prawira Fotografi ada beberapa hal yang harus diperhatikan antara lain: pemilihan merek, evaluasi, tujuan bisnis, peraturan, promosi, dan strategi pemasaran.

3. Interaksi Simbolik yang terjadi pada Hann Prawira Fotografi sangat mempunyai peran penting dalam proses pemotretan yang dilakukan.

\section{Ucapan Terima Kasih}

Penelitian ini dapat diselesaikan karena mendapatkan bantuan serta dukungan dari banyak pihak. Oleh karena itu, peneliti mengucapkan banyak terima kasih yang sebesar-besarnya kepada Burhan Prawira selaku pemilik dari Hann Prawira Fotografi atas ketersedian nya dalam membantu penulis menyelesaikan penelitian ini, juga peneliti sampaikan ucapan terima kasih untuk semua informan yang terlibat dalam penelitian ini.

\section{Daftar Pustaka}

Pribadi, M. A., Suganda, D. V. A \& Susanto, E. H. (2018). Dinamika Perusahaan Periklanan Indonesia: Studi Kasus Komunikasi dan Budaya Organisasi Dwi Sapta IMC dan Fortjne Indonesia. Disertasi Universitas Padjajaran. Bandung: Universitas Padjajaran.

West, R., \& Turner, L, H. (2013). Pengantar Teori Komunikasi: Analisis dan Aplikasi. Jakarta: Salemba Humanika.

Yin, Robert K. (2014). Studi kasus: Desain \& Metode. Rajagrafindo Persada. Jakarta 